\title{
Analysis of Efficiency of Use of Factors Production Rice Farming Polluted and Unpolluted By Slaughterhouses Waste In Penggaron Kidul Semarang
}

\author{
Ashilah Zahra Lubis ${ }^{1 *}$, Bambang Mulyatno Setiawan ${ }^{2}$, Edy Prasetyo ${ }^{2}$ \\ Agribusiness Program, Faculty of Animal Husbandry and Agriculture, Diponegoro University, Semarang \\ Received: 9 March 2020; Revised: 22 June 2020; Accepted: 24 February 2021
}

\begin{abstract}
Penggaron Kidul is a village in Pedurungan that owns rice fields located around Slaughterhouse (RPH). It causes the rice fields polluted by waste and makes the rice productivity is not optimal. This research aimed to analyze the production factors that affected the amount of rice production, the use of production factors level, and the economic efficiency differences in the use of production factors in polluted and unpolluted fields. The survey method was employed in this research by interviewing the members of Dharma Tani Farmers using a questionnaire. The sampling method used was proportionate stratified random sampling used two populations with 80 people. The number of samples was 66 respondents categorized into 33 farmers (landowners of polluted fields) and 33 farmers (landowners of unpolluted fields). The data analysis conducted using a linear regression analysis method, analysis of Independent Sample T-test, and analysis of technical and economic efficiency then tested using analysis One Sample T-test. The result showed that the use of the land area, labor, and dummy variable of location significantly affected the amount of rice production while the factors of seed, fertilizer, and pesticides did not significantly affect the amount of rice production. The production factors of fertilizer and labor in polluted land had no different from unpolluted fields while the factors of seed and pesticides in polluted fields were different from unpolluted fields. Meanwhile, the production factors of seeds and pesticides in polluted fields were greater than in unpolluted fields. The use of production factors of land area, seeds, fertilizers, pesticides, and labor was technically and economically inefficient. The efficiency economic of production factors in polluted fields is different from unpolluted fields which unpolluted fields are more efficient than polluted fields.
\end{abstract}

Keywords: efficiency; factors; rice; production

How to cite:

Lubis, A. Z., Setiawan, B. M., \& Prasetyo, E. (2021). Analysis of Efficiency of Use of Factors Production Rice Farming Polluted and Unpolluted By Slaughterhouses Waste In Penggaron Kidul Semarang. HABITAT, 32(1), 17-25. https://doi.org/10.21776/ub.habitat.2021.032.1.3

\section{Introduction}

The agricultural sector is one factor that contributes to Indonesia's economic growth due to the demand for food needs continuously increasing every year. Supported by the data from Produk Domestik Bruto (PDB) based on the existed price of the business sector in the year 2018 showed agricultural sector became the second most influential factor for the nation's economic condition by $13.63 \%$ (BPS, 2017). Many subsectors construct the agricultural sector, and then one of them known as crops. Crops, particularly rice plants, may help in providing

*Correspondence Author.

E-mail: ashilahzahralubis@students.undip.ac.id food needs for Indonesians. The farming activities by the farmers may fulfill the food needs.

Kidul Penggaron Sub-district has one of the largest rice fields in Pedurungan District by 102.64 hectares. This sub-district has a farmer group that has duties to cultivate rice plants in three rice fields called the Dharma Tani farmer group. One rice field located around the slaughterhouse (RPH) polluted. Waste contaminating rice fields contains feces, rumen's contents, blood, and laundry water from the slaughterhouse. The continuous waste pollution produces black rice plants (grain) and makes rice production not optimal. Waste contamination may affect land productivity due to the waste has not been decomposed completely and may damage the plants, so rice plant growth is 
inhibited. Waste that pollutes rice fields continuously in the long term can affect rice productivity (Aini et al., 2017). Efforts to optimize rice production can be done using production factors as efficiently as possible technically and economically (Kaban et al., 2012).

The purposes of this study are to analyze the influence of production factors, the location of farming towards the amount of rice production, the use level of production factors, and the comparison of the economic efficiency of the production factors used in the polluted fields and not polluted by the slaughterhouse waste.

\section{Research Methodology}

The study was carried out in November December 2019 in the Kidul Penggaron Subdistrict, Pedurungan District, Semarang City. The location was determined purposively by considering the research location adjacent to the slaughterhouse (RPH) and the same environmental characteristics between polluted fields and not polluted by RPH waste.

The research methodology was the survey method. The data used was primary data obtained through surveys and interviews with the Dharma Tani farmer group's members with questionnaire tools. Additionally, secondary data obtained from references, Central Statistics Agency, Agricultural Technology Assessment Center, Agriculture Department, Books, and Journals. The sampling method used the cluster random sampling method. The sampling done in two populations of the Dharma Tani farmer group's members using the Slovin formula. Therefore, the samples used were 66 respondents consisting of 33 farmers of rice fields polluted with waste and 33 farmers of rice fields that were unpolluted.

\subsection{Data Analysis Methodology}

Mulltiple linear regression test was carried out to analyse the data with the function of the COBB-Douglas model to measure the influence between the independent variables namely land area (X1), seeds (X2), Fertilizer (X3), Pesticides (X4), Labor (X5) and Location (X6) against the dependent variable, namely the amount of rice production $(\mathrm{Y})$ using the SPSS 21 program. The regression equation used as follows (Soekartawi, 2003):

$$
\begin{gathered}
\mathrm{LnY}=\operatorname{Ln} \alpha+\beta_{1} \operatorname{LnX}_{1}+\beta_{2} \operatorname{LnX}_{2}+\beta_{3} \operatorname{LnX}_{3}+ \\
\beta_{4} \operatorname{LnX}_{4}+\beta_{5} \operatorname{LnX} X_{5}+\beta_{6} \operatorname{LnX}_{6}+\mathrm{V}
\end{gathered}
$$

Explanation:

$\mathrm{Y}=$ the amount of rice production $(\mathrm{kg})$

$\mathrm{X}_{1}=$ land area (ha)

$\mathrm{X}_{2}=$ seeds $(\mathrm{kg})$

$\mathrm{X}_{3}=$ Fertilizer $(\mathrm{kg})$

$\mathrm{X}_{4}=$ Pesticides (liter)

$\mathrm{X}_{5}=$ Labor (HOK)

$\mathrm{X}_{6}=$ Dummy Location $(\mathrm{D}=0$ polluted rice fields; $\mathrm{D}=1$ unpolluted rice fields)

$\mathrm{V} \quad=$ Error Rate

$\alpha=$ Constant

$\beta_{1-} \beta_{6}=$ Regression Coefficient of each variable

Technical analysis might be found through the elasticity of production, namely in the equation $\mathrm{Ep}=$ bi. The elasticity of production could be written in the following equation (Pakasi et al., 2011):

$\mathrm{Ep}=\frac{\partial \mathrm{Y}}{\partial \mathrm{Xi}} \times \frac{\mathrm{Xi}}{\mathrm{Y}}$

$\mathrm{Ep}=\mathrm{bi} \times \frac{\mathrm{Xi}}{\mathrm{Y}} \times \frac{\mathrm{Y}}{\mathrm{Xi}} \quad \mathrm{Ep}=\mathrm{bi}$

In which:

1. $\mathrm{Ep}=1$, when the average production reached the maximum $(\mathrm{AP}=\mathrm{MP})$

2. $\mathrm{Ep}=0$, when the marginal product $(\mathrm{MP})=0$ when AP decreased ane TP was optimum

3. Ep $>1$, when the total product (TP) increased and the average production (AP) increased

4. $0<\mathrm{Ep}<1$, when MP and AP has decreased and the value is positive. This area was an efficient production area

5. Ep $<0$, it was impossible for the company to continue production because the addition of input would reduce the total production.

Economic efficiency analysis calculated by comparing the marginal physical product (NPM) of each production factor with the price of each production factor (Rahayu and Riptanti, 2010). The formula for economic efficiency could be written as follows:

In which:

$$
\mathrm{EE}=\frac{\mathrm{NPMx}}{\mathbf{P x}}
$$

a) If $\frac{\mathrm{NPMx}}{\mathrm{Px}_{\text {efficient yet, so input } X \text { must be added }}}>1$ then the use of input $X$ was not

b) If $\frac{\mathbf{N P M x}}{\mathrm{Px}}=1$ then the use of input $X$ was efficient

c) If $\frac{\mathrm{NPMx}}{\mathrm{Px}}<1$ then the use of input $\mathrm{X}$ was inefficient so input $\mathrm{X}$ must be reduced 
Economic efficiency was tested using the one-sample t-test which aimed to compare the value of economic efficiency in the use of production factors with the value of economic efficiency criteria (test value $=1$ ). The onesample t-test used to compare certain values with a criterion (Santoso, 2016).

$\mathrm{H}_{0}$ dan Ha Determination

$\mathrm{H}_{0}=1$, meant the use of production factors on polluted land and unpolluted was economically efficient.

$\mathrm{Ha} \neq 1$, meant the use of production factors on polluted land and unpolluted was economically inefficient.

\section{Results and Discussions}

\subsection{The Characteristics of Respondents}

The findings showed that the farmers who mostly cultivate rice on polluted and unpolluted fields were aged 45-59 years, namely 20 people $(64.52 \%)$, so they were categorized as productive ages due to the working ages group was ranged from 22 - 59 years old (Ariwidodo, 2016). The formal educational level aspect showed that the farmers in both fields were the high school graduates by $54.84 \%$ and $45.16 \%$, so it included in the medium category. The educational level of farmers affected their knowledge, insight, and ability to make a decision. The farmers' formal education was the capital in carrying out farming activities because it might increase their insights and experiences (Panggabean et al., 2016). The highest number of family dependents of farmers on both fields was 4 - 6 people by $77.42 \%$ and $74.20 \%$, so it included the medium category. Additionally, it might give a positive impact on the farmers' income allocation to meet family needs. Following the opinion of Hafsah (2003), the greater the number of family dependents, the greater the effort made in increasing productivity to meet the daily needs. Most farmers had experience in farming in both fields for 20-24 years $(58.07 \%$ and $48.40 \%)$. The longer the farming experience, the better attitude shaped in managing the farm to provide a high profit. Panggabean et al. (2016) stated that both experience and ability of farmers in farming activities could be a way to fulfill the daily needs as well as provide benefits for them.

\subsection{The Use of Production Factors}

The production factors used in rice farming on polluted and unpolluted fields by slaughterhouse waste were land area, seeds, fertilizers, pesticides, and labor. The averages use of production factors in the Dharma Tani Farmer Group presented in Table 1 as follows:

Table 1. The averages use of production factors in rice farming on polluted and unpolluted fields by slaughterhouse waste

\begin{tabular}{|c|c|c|c|c|c|c|}
\hline \multirow[b]{2}{*}{ No } & \multirow[b]{2}{*}{ Production Factor } & \multirow[b]{2}{*}{ Unit } & \multicolumn{2}{|c|}{ Polluted } & \multicolumn{2}{|c|}{ Unpolluted } \\
\hline & & & Average & $\begin{array}{l}\text { Standard } \\
\text { Deviation }\end{array}$ & Average & $\begin{array}{l}\text { Standard } \\
\text { Deviation }\end{array}$ \\
\hline 1. & Land Area & ha & 0,19 & 0,11 & 0,23 & 0,13 \\
\hline 2. & Seeds & $\mathrm{kg}$ & 16,94 & 7,92 & 16,61 & 10,28 \\
\hline 3. & Fertilizer & $\mathrm{kg}$ & 150,00 & 52,84 & 167,74 & 87,13 \\
\hline 4. & Pesticide & Liter & 0,91 & 0,57 & 0,79 & 0,46 \\
\hline 5. & Labor & $\mathrm{HOK}$ & 41,88 & 4,47 & 42,24 & 3,43 \\
\hline
\end{tabular}

Table 1 showed that the average land-use area of 0.19 hectares for polluted fields and 0.23 hectares for unpolluted which indicated that the land area for rice farming was below standard. According to Nazam et al. (2011), the minimum land area for planting rice was 0.73 hectares. The land area was one of the determinants in the production factors of farming to produce agricultural products optimally. Standing at the same opinion, Eliza et al. (2010) stated that land area was one of the most important production factors in determining the production level.

The average seeds used during the rice farming activities in both fields were $16.94 \mathrm{~kg}$ and $16.61 \mathrm{~kg}$ respectively. It was equivalent to the seeds used by $92.04 \mathrm{~kg} / \mathrm{ha}$ on the polluted and $74.29 \mathrm{~kg} / \mathrm{ha}$ on the unpolluted field. It classified as high and done by farmers in an effort to anticipate the rice plants that would grow. The use of rice seeds exceeded the existing standards, namely $20-25 \mathrm{~kg} / \mathrm{ha}$. In accordance with the 
opinion of Purwono and Purnamawati (2007) that the need for rice seeds on an area of one hectare was 20-25 kilograms. The use of the right seeds might affect the amount of production. Susanti et al. (2018) stated that the adjusted number of superior seeds to the needs and field area could increase production.

The average uses of urea fertilizer for rice in both fields were $150 \mathrm{~kg}$ and $167.74 \mathrm{~kg}$. This is equivalent to fertilizer used of $859.02 \mathrm{~kg} / \mathrm{ha}$ on the polluted fields and $785.02 \mathrm{~kg} / \mathrm{ha}$ on the unpolluted fields. The use of fertilizers on polluted fields was higher because farmers did not consider the waste from the slaughterhouse contained feces that could be used as additional organic fertilizer. According to Anhar et al. (2016), the use of good urea fertilizer to increase rice production in the normal field ranges from $200-250 \mathrm{~kg} / \mathrm{ha}$. The amount of fertilizer must be adjusted to the needs of the plant so that the growth and development were going well. Gunawan (2018) stated that applying the right amount of fertilizer to plants according to the needs could boost optimal production.

The average uses of pesticides in polluted and unpolluted fields were 0.91 and 0.79 liters. This was equivalent to 4.90 liters/ha on polluted fields and 3.84 liters/ha on unpolluted. The use of pesticides on polluted fields tended to be higher due to the waste produced smell that invited animals around to come so it could interfere the rice plants' growth. Hildayanti et al. (2013) stated that the use of pesticides by farmers using inorganic fertilizers was 0.43 liters/ha. The use of pesticides was adjusted to the number of pests that attacked rice plants to minimize negative impacts. This was in accordance with the opinion of Eliza et al. (2010) that the use of pesticides that were inappropriate to the needs of the plant could inhibit plant growth and development.

The average uses of labor in polluted and unpolluted fields were $41.88 \mathrm{HOK}$ and 42.24 HOK. This was equivalent to the use of the labor of $270.73 \mathrm{HOK} / \mathrm{ha}$ on polluted and 257.55 $\mathrm{HOK} / \mathrm{ha}$ on unpolluted fields. It tended to be higher than the existing standards. Hernanto (2006) stated the use of labor in farming activities was around $159 \mathrm{HOK} / \mathrm{ha}$. The labor used by the Dharma Tani Farmer Group came from the family and outside the family. Outside the family, the laborers who employed were contract laborers of 10 - 20 people for land management and harvesting. According to Mubyarto (2002), the labor in farming could come from the farming family as well as outside to manage the farming activities as a whole.

\subsection{Analysis of the Effect in the Use of Production Factors on Rice Production}

Multiple linear regression analysis was a statistical analysis to measure the effect of independent variables on the dependent variables. The results of multiple linear regression analysis with the Cobb-Douglas model in the natural logarithm form as follows:

$$
\begin{aligned}
\operatorname{Ln} Y= & 6,052+0,528 \operatorname{LnX}_{1}+0,169 \operatorname{LnX}_{2}- \\
& 0,129 \operatorname{LnX}_{3}+0,108 \operatorname{LnX}_{4}-0,731 \operatorname{LnX}_{5} \\
& +0,036 \operatorname{LnX}_{6}
\end{aligned}
$$

Based on the regression equation above, the constant value obtained was 6.052. The results of the regression coefficients on the seeds, fertilizers, pesticides, labor, and location dummy variables were $0.528 ; 0.169 ;-0,129 ; 0.108$; 0.731 , and 0.036. According to Ariningsih and Mertha (2017), the regression coefficient which had a positive value means that if the independent variable (X) increased by $1 \%$, the dependent variable $(\mathrm{Y})$ would increase by the value of the regression coefficient assuming the other variables were fixed, and vice versa.

Table 2. The Results of Multiple Linear Regression

\begin{tabular}{clccc}
\hline No & Variable & Coefficient & $\begin{array}{c}\text { T- } \\
\text { value }\end{array}$ & Sig. \\
\hline 1. & Constant & 6,052 & 5,003 & $0,000^{\mathrm{s}}$ \\
2. & Land & 0,528 & 3,943 & $0,000^{\mathrm{s}}$ \\
& Area & 0,169 & 1,299 & $0,199^{\text {ns }}$ \\
3. & Seeds & $-0,129$ & $-0,882$ & $0,382^{\text {ns }}$ \\
4. & Fertilizer & 0,108 & 1,539 & $0,130^{\text {ns }}$ \\
5. & Pesticide & $-0,731$ & $-2,450$ & $0,017^{\mathrm{s}}$ \\
6. & Labor & 9,588 & $0,000^{\mathrm{s}}$ \\
7. & Location & 0,036 & \\
\hline \multicolumn{5}{l}{ F value $=48,561$} \\
\hline & Sig. $=0,000$ \\
\hline & Adjusted R Square $=0,824$ \\
\hline
\end{tabular}

Explanation: $\mathrm{s}=$ significant $\mathrm{ns}=$ not significant

The results of the analysis showed that the sig. $\mathrm{F}$ on the production factors in polluted and unpolluted fields had a value of 0,000 . It portrayed that the significance value $\alpha \leq 0.05$ meant that the variables of seeds, fertilizers, pesticides, and labor had a simultaneous effect on the amount of rice production. Following Ghanimata (2012), the rules for the acceptance of $\mathrm{H} 0$ if the significance value of $\alpha>0.05$ then $\mathrm{Ha}$ was rejected, and if $\alpha \leq 0.05$ then $\mathrm{H} 0$ was 
rejected and $\mathrm{Ha}$ was accepted. Shortly, it displayed that the independent variable affected the dependent variable simultaneously.

The t-test displayed the land area (X1) had a significance value of 0.000 indicated that it carried on a very significant effect on the amount of rice production. Land area was an important factor in production input because the more land was used, the more plants would grow, and the greater the production would be. Eliza et al. (2010) stated that one of the important factors in production input was land area because it could determine the amount of production.

The seeds variable (X2) had a significance value of 0.199 , which displayed that the seed variable brought no effect on the amount of rice production. Due to the seeds used by the Dharma Tani Farmer Group was not following the standards, so it affected the amount of production. Susanti et al. (2018) said that the number of superior seeds used must adjust to the needs, so it could increase the amount of production.

The fertilizer variable (X3) gave no significant effect on the amount of production because the significance value was 0.382 , which indicated $\alpha>0.05$. The use of urea fertilizer was not in accordance with the recommendations so that it needed to be reduced properly to the plants' needs. Following the opinion of Notarianto and Pujiyono (2011), fertilizer was an important factor besides land area and seeds that could increase production yield if the dose given was appropriate.

The pesticide variable (X4) had a significance value of 0.130 , which indicated $\alpha>$ 0.05 . The pesticide had no effect on the amount of rice production. The use of pesticides on polluted and unpolluted fields was classified as high and exceeded the existing standards, namely 0.43 liters/ha. According to Eliza et al. (2010), the pesticides given to plants with inappropriate doses could inhibit plant growth.

The labor variable (X5) had a significant effect on the amount of rice production because the significance value was 0.017 . Labor was one of the key factors in farming, so the quantity and quality of its use needed to be taken into account. According to Soekartawi (2003), the use of labor needed to be considered, not only about the availability but also from its quality.

The location dummy variable had a very significant effect on the amount of rice production with a regression coefficient of 0.036 . It because the polluted fields had lower rice production, namely $4,084 \mathrm{~kg}$ compared to the unpolluted fields, namely $6,368 \mathrm{~kg}$ for an average land area of 1 hectare. The amount of rice production in polluted fields was not optimal due to contamination of waste from slaughterhouses containing feces of poultry, cows, and pigs so that the growth of rice plants was disrupted. This was in accordance with the opinion of Mulyani et al. (2015) stated that RPH waste generally contained compounds that were destructive and disrupted the presence of other biotas in the vicinity such as BOD, COD, oil, fat, and NH3-N.

The coefficient of determination (R2) obtained was 0.824 or $82.4 \%$, which showed that $82.4 \%$ of the independent variables could explain the dependent variable, and the remaining $27.6 \%$ was explained by other variables outside. It displayed that the use of these production factors could explain the rice production variables quite well. Ghanimata (2012) stated that a small coefficient of determination defined that the ability of the independent variable to explain the dependent variable was very limited.

\subsection{Independent Sample T-Test Testing}

Based on the analysis of the independent sample t-test, the seed variable had a significance of 0.001 indicated that there were differences in the use of seed production factors on polluted and unpolluted fields. According to Ashari and Sukarsa (2013), if the significance value $\alpha \leq$ 0.05 , there was a difference, and if $\alpha>0.05$, there was no difference. The average use of seeds on the polluted fields was higher by $92.04 \mathrm{~kg} / \mathrm{ha}$ than unpolluted fields by $74.29 \mathrm{~kg} / \mathrm{ha}$. It was conducted to anticipate plants that would grow due to plants' opportunity to grow in polluted fields was smaller. The fertilizer variable had a value of 0.131 indicated that the significance value $\alpha>0.05$ showed there was no difference in the use of fertilizers on polluted and unpolluted fields. The use of fertilizers on both fields was $859.02 \mathrm{~kg} / \mathrm{ha}$ and $785.02 \mathrm{~kg} / \mathrm{ha}$. The use of urea fertilizer on polluted fields was higher because farmers did not consider slaughterhouse waste containing feces could be used as additional organic fertilizer. Fertilizer was one of the production factors that could increase production if it was used properly with needs (Notarianto and Pujiyono, 2011).

The pesticide variable has a significance value of 0.035 indicated differences in pesticides used for both fields. The average use of pesticides on polluted fields was higher by 4.90 liters/ha than unpolluted by 3.84 liters/ha. 
Because the waste that polluted the rice fields raised a smell that invited the animals around to come closer, so the plants' growth could be inhibited. Eliza et al. (2010) stated that the excessive use of pesticides could interfere with plant growth.

The labor variable brought a significance value of 0.420 , which indicated no difference in the use of labor on polluted and unpolluted fields. It because the Dharma Tani Farmer Group employed contract laborers for land management and harvesting, so the number of workers used was equal between members of the farmer group. The use of labor must be adjusted to the farm's needs to minimize production costs. According to Dewi and Yuliarmi (2017), the use of proper laborers properly to the needs could increase production.

\subsection{Technical Efficiency}

Based on the test's results, the technical efficiency of using the production factor for the land area was 0.528 . It showed that the use of the production factor for the land area was technically inefficient because it was not suitable with the recommended provisions. Therefore, if there was an increase in land area, it would be increasingly inefficient. The wider agricultural land did not guarantee the efficiency of the land because too large could lead to inefficiencies in the use of production factors in farming (Soekartawi, 2003).

The elasticity value of seed variable production was 0.169 . This value showed less than 1 meant it was technically inefficient, therefore it was necessary to reduce the use of seed production factors. it happened because the use of seeds was not appropriate with the use of land area so it affected the rice production. Susanti et al. (2018) stated that the amount of seeds used in the production process was adjusted to the needs to increase production.

The elasticity value of fertilizer production obtained was -0.129 , which indicated the value was less than 1 so that the use of fertilizer production factors was technically inefficient. Therefore, it was necessary to reduce the use of fertilizer production factors. The use of fertilizers that were not suitable for plant nutrient needs could inhibit plant growth. According to Gunawan (2018), the use of fertilizers given to plants was adjusted to soil fertility and plant needs because it affected plant growth and production.
The elasticity value of pesticide production obtained was 0.108 , which indicated that this value was technically inefficient. Therefore, it was necessary to reduce the use of pesticide production factors because the dosage used exceeded the recommended. Excessive use of pesticides brought a negative impact on the environment. According to Khazanani (2011), excessive use of pesticides caused environmental pollution and damaged agricultural commodities.

The elasticity value of labor production obtained was $-0.731 \mathrm{~s}$. This value was less than 1 , which indicated that the use of labor production factors was technically inefficient. Therefore, it was necessary to reduce labor production factors. There were too many laborers were employed in farming activities, the rice production was not proportional to the labor used because the proper use of labor would affect agricultural productivity. Dewi and Yuliarmi (2017) stated that the use of appropriate labor would increase results in the production process.

\subsection{Economic Efficiency}

Based on the research results, the results of economic efficiency presented in Table 3 as follows:

Table 3. The Results of Economic Efficiency Analysis

\begin{tabular}{lrr}
\hline \multirow{2}{*}{ Variable } & Unpolluted & \multicolumn{1}{c}{ Polluted } \\
\cline { 2 - 3 } & $\begin{array}{c}\text { Economic } \\
\text { Efficiency }\end{array}$ & $\begin{array}{l}\text { Economic } \\
\text { Efficiency }\end{array}$ \\
\hline Land Area & 0,003 & 0,002 \\
Seeds & 4,386 & 2,597 \\
Fertilizer & $-1,842$ & $-1,030$ \\
Pesticide & 6,245 & 3,349 \\
Labor & $-1,106$ & $-0,614$ \\
\hline
\end{tabular}

The results of the economic efficiency analysis showed that the economic efficiency value of the use of production factors for the land area on unpolluted fields was 0.003 . Therefore, it showed that the use of the land area was economically inefficient because it valued less than 1. It was because the use of the land area was only $2.285,48 \mathrm{~m} 2$ also the combination of the use of other production factors was inappropriate, so the production was not optimal. Nazam et al. (2011) stated that the minimum use of rice land area for farming was 0.73 hectares. The value of economic efficiency using the production factor of land area on polluted fields was 0.002 indicated it was not economically efficient. It was due to the use of production 
factors mixed with slaughterhouse waste which contained toxic compounds, thus plant growth was disrupted that impacted the low rice production. Mulyani et al. (2015) stated that slaughterhouse waste generally contain NH3-N, $\mathrm{BOD}, \mathrm{COD}$, oil, and fat compounds which gave an impact on the presence of surrounding biota.

The economic efficiency values of the seed production factor on polluted and unpolluted fields were 4.386 and 2.597. It indicated that the use of the seed production factor was inefficient because the value was more than 1 , so it needed additional production factors. The average uses of seeds were $92.04 \mathrm{~kg}$ and $74.29 \mathrm{~kg}$ for an average land area of 1 hectare, which meant that the use of seeds was higher than the stipulated amount of $20-25 \mathrm{~kg}$ per 1 hectare. It was because the farmers' attitude in conducting farming did not consider the number of seeds to be planted with the existing land area, besides farmers in polluted fields applied more seeds due to the chances of growing plants were smaller than unpolluted fields. According to Juanda (2016), the use of rice seeds was generally around 25 $\mathrm{kg} /$ hectare.

The economic efficiency values of the fertilizer production factor on polluted and unpolluted fields were -1.030 and -1.842 . It indicated that the fertilizer production factor was inefficient because the values were less than 1 , so there was no need to add the fertilizer production factor. This was due to the use of fertilizers that tended to be high so that the need for plants was too excessive which could cause plants to be susceptible to pests and diseases. According to Yanti et al. (2014), excessive fertilizer application caused damage to plant growth, plants to fall, and was vulnerable to pests.

The economic efficiency values of the pesticide production factor on polluted and unpolluted fields were 6,245 and 3,349. It indicated that the use of pesticides was economically inefficient because the value was more than 1 . The average uses of pesticides on both fields were 4.90 liters/ha and 3.84 liters/ha which exceeded the recommendation of 0.43 liter/ha. It was because rice plants were very vulnerable to pests, so farmers often sprayed rice plants. Furthermore, waste contained unpleasant odors that could invite animals around so that it interfered with the growth of rice plants. Hildayanti et al. (2013) stated that the use of pesticides in rice farming was around 0.43 liters/ha. Supported by the opinion of Subadyo (2017) that the unpleasant odor produced from animal waste was one of the causes for plants to be attacked by pests.

The economic efficiency values of labor production factors on polluted and unpolluted fields fields were -1.106 and -0.614 . The values indicated that the labor production factor was inefficient because it was less than 1 . The average uses of labor on both fields were 270.73 $\mathrm{HOK} / \mathrm{ha}$ and $257.55 \mathrm{HOK} / \mathrm{ha}$ indicated the use of labor tended to be high so that it caused inefficiencies in the production process. According to Hernanto (2016), the use of labor in farming was generally $159 \mathrm{HOK} / \mathrm{ha}$.

Table 4. The Results of One Sample T-test

\begin{tabular}{llrr}
\hline No & Variable & $\begin{array}{c}\text { Polluted } \\
\text { Sig. (2-tailed) }\end{array}$ & $\begin{array}{c}\text { Unpolluted } \\
\text { Sig. (2-tailed) }\end{array}$ \\
\hline 1. & Land & $0,000^{\mathrm{s}}$ & $0,000^{\mathrm{s}}$ \\
2. & Area & $0,000^{\mathrm{s}}$ & $0,000^{\mathrm{s}}$ \\
3. & Pupuk & $0,000^{\mathrm{s}}$ & $0,000^{\mathrm{s}}$ \\
4. & Pestisida & $0,000^{\mathrm{s}}$ & $0,000^{\mathrm{s}}$ \\
5. & Tenaga & $0,000^{\mathrm{s}}$ & $0,000^{\mathrm{s}}$ \\
\hline
\end{tabular}

The level of economic efficiency in the use of production factors for polluted and unpolluted fields could be determined through the onesample t-test. The one-sample t-test was conducted using the test value 1 as the test value of the criteria for economic efficiency. Based on the results of the analysis, it was found that the significance value of the use of production factors on polluted and unpolluted fields was less than 0.05 . This value indicated the significance value $\alpha \leq 0.05$ showed that there was a difference in the value of economic efficiency towards the use of production factors with the value of economic efficiency criteria so that the use of production factors was economically inefficient. According to Santoso (2016), if the value $\alpha \leq$ 0.05 then $\mathrm{H} 0$ was rejected and $\mathrm{Ha}$ was accepted. This indicated that there was a difference in the value of economic efficiency with 1 so the production factors used were economically inefficient. If the value $\alpha>0.05$ then $\mathrm{H} 0$ was accepted and $\mathrm{Ha}$ was rejected, there was no difference in the value of economic efficiency with 1 , so the production factors used were economically efficient.

\section{Conclusion}

In conclusion, the production factors of land area, seeds, fertilizers, pesticides, labor, and location have a significant effect simultaneously 
on the amount of rice production. The production factors of land area, labor, and location are partially significant for the amount of production. Meanwhile, the other variables such as seeds, fertilizers, and pesticides do not have a partial effect on the amount of production. The number of seeds and pesticides used in polluted fields is significantly different from unpolluted fields, while the amount of fertilizers and labor used is not significantly different. The factors of production such as land area, seeds, fertilizers, pesticides, and labor are technically and economically inefficient. The economic efficiency of using production factors on polluted fields is different from the economic efficiency of using production factors on unpolluted fields.

\section{References}

Aini, M. Sriasih dan D. Kisworo. 2017. Studi pendahuluan cemaran air limbah rumah potong hewan di Kota Mataram. Jurnal Ilmu Lingkungan. 15 (1): $42-48$.

Anhar, R., E. Hayati dan Efendi. Pengaruh dosis pupuk urea terhadap pertumbuhan dan produksi plasma nutfah padi lokal asal Aceh. Jurnal Kawista. 1 (1): 30 - 36.

Ariningsih, P. S. dan I. M. Mertha. 2017. Pengaruh independensi, tekanan anggaran waktu, risiko audit dan gender pada kualitas audit. Jurnal Akuntansi Udayana. 18 (2): 1545 - 1574.

Ariwidodo, E. 2016. Kontribusi pekerja perempuan pesisir sektor rumput laut di Bluto Kabupaten Sumenep. Jurnal Nuansa. 13 (2): $329-356$.

Ashari, A. A. Y. dan I. M. Sukarsa. 2013. Analisis efisiensi produksi usaha peternakan ayam ras pedaging di Kabupaten Tabanan. Jurnal Ekonomi dan Bisnis. 2 (6): 394 - 408.

Dewi, F. G., J. J. M. R. Londok, R. A. V. Tuturoong dan W. B. Kaunang. 2013. Pengaruh pemupukan anorganik dan organik terhadap produksi tanaman jagung sebagai sumber pakan. Jurnal Zootek. 32 (5): $1-8$.

Eliza, S. Tarumun dan Yusmini. 2010. Pengaruh faktor produksi terhadap produksi kelapa hibrida pola plasma di Kabupaten Indragiri Hilir. Jurnal Ilmu Pertanian Ekonomi Indonesia. 1 (1): 49 - 62.
Ghanimata, F. 2012. Analisis Pengaruh Harga, Kualitas Produk dan Lokasi terhadap Keputusan Pembelian (Studi pada Pembeli Produk Bandeng Juwana Elrina Semarang). [Skripsi]. Semarang: Universitas Diponegoro.

Gunawan, F. 2018. Pengaruh penggunaan faktor produksi terhadap produksi padi di Desa Barugae Kabupaten Bone. Jurnal Pertanian. 1 (1): 1 - 15.

Hafsah, M. J. 2003. Bisnis Ubi Kayu Indonesia. Pustaka Sinar Harapan, Jakarta.

Hernanto, F. 2006. Ilmu Usahatani. Penebar Swadaya, Jakarta.

Hildayanti, S. K., A. Mulyana, Sriati dan N. Gofar. 2013. Pendapatan petani padi sawah pengguna pupuk organik dan anorganik di Kabupaten Ogan Komering Ulu (Oku) Timur. Jurnal Agrisep. 12 (2): 195 - 208.

Juanda, B. R. 2016. Peningkatan produksi padi melalui potensi dan pengembangan wilayah produksi benih unggul di Propinsi Aceh. Jurnal Agrosamudra. 3 (2): $72-80$.

Kaban, T. F., R. Ginting dan Iskandarini. 2012. Analisis efisiensi penggunaan faktor produksi pada usahatani padi sawah di Desa Sei Belutu Kecamatan Sei Bamban Kabupaten Serdang Bedagai. Jurnal Pertanian dan Agribisnis Sosio-Ekonomi. 1 (1): $1-14$.

Khazanani, A. 2011. Analisis Efisiensi Penggunaan Faktor-Faktor Produksi Usahatani Cabai Kabupaten Temanggung. [Skripsi]. Semarang: Universitas Diponegoro.

Mubyarto, 2002. Pengantar Ekonomi Pertanian Edisi Ketiga. LP3ES, Jakarta.

Mulyani, E., Supriyatin dan M. T. S. Johnny. 2015. Dampak limbah cair rumah potong hewan sapi terhadap kualitas air drainase di Nipah Kuning Kota Pontianak. Jurnal Teknologi Lingkungan Tanah Basah. 3 (1): $1-10$.

Nazam, M., S. Sabiham, B. Pramudya, Widiatmaka dan I. W. Rusastra. 2011. Penetapan luas lahan optimum usahatani padi sawah mendukung kemandirian pangan berkelanjutan di Nusa Tenggara Barat. Jurnal Agro Ekonomi. 29 (2): 113 145. 
Notarianto, D. dan A. Pujiyono. 2011. Analisis efisiensi penggunaan faktor-faktor produksi pada usahatani padi organik dan padi anorganik. Jurnal Pembangunan Ekonomi. 1 (1): 1 - 28.

Pakasi, C. B. D., L. Pangemanan, J. R. Mandei dan N. N. I. Rompas. 2011. Efisiensi penggunaan faktor produksi pada usahatani jagung di Kecamatan Remboken Kabupaten Minahasa. Jurnal ASE. 7 (2): $51-60$.

Panggabean, M. T., S. Amanah dan P. Tjitropranoto. 2016. Persepsi petani lada terhadap diseminasi teknologi usahatani lada di Bangka Belitung. Jurnal Penyuluhan. 12 (1): 61 - 73.

Purwono dan H. Purnamawati. 2007. Budidaya 8 Jenis Tanaman Pangan Unggul. Penebar Swadaya, Jakarta.

Rahayu, W. dan E. W. Riptanti. 2010. Analisis efisiensi ekonomi penggunaan faktorfaktor produksi pada usahatani kedelai di Kabupaten Sukoharjo. J. Caraka Tani. 25 (1): $119-125$.

Santoso, S. 2016. Panduan Lengkap SPSS versi 23. PT Elex Media Komputindo, Jakarta.

Soekartawi. 2003. Teori Ekonomi Produksi dengan Pokok Bahasan Analisis CobbDouglas. PT. Raja Grafindo Persada, Jakarta.

Subadyo, A. T. 2017. Pengelolaan dampak pembangunan rumah potong hewan ruminansia di Kota Batu. J. Pengabdian Masyarakat. 2 (2): 15 - 20.

Susanti, H., K. Budiharjo dan M. Handayani. 2018. Analisis pengaruh faktor-faktor produksi terhadap produksi usahatani bawang merah di Kecamatan Wanasari Kabupaten Brebes. Jurnal Sosial Ekonomi Pertanian. 2 (1): 23 - 30.

Yanti, S. E. F., E. Masrul dan H. Hannum. 2014. Pengaruh berbagai dosis dan cara aplikasi pupuk urea terhadap produksi tanaman sawi (Brassica juncea L.) pada tanah inceptisol marelan. Jurnal Agroekoteknologi. 2 (2): 770 - 780. 